Open Access

\title{
Challenges and prospects of entrepreneurship development and job creation for youth unemployed: evidence from Addis Ababa and Dire Dawa city administrations, Ethiopia
}

\author{
Abel Tewolde Mehari ${ }^{1}$ and Christian Feleke Belay ${ }^{2^{*}}$
}

\author{
* Correspondence: \\ Legashtiwilid@gmail.com \\ ${ }^{2}$ Haramaya University, Dire Dawa, \\ Ethiopia \\ Full list of author information is \\ available at the end of the article
}

\begin{abstract}
This research paper is on youth employment and entrepreneurship. It has investigated a total of 3591 youths in two different geographical areas of Ethiopia. Entirely, it has taken three specific villages: Melka Jebdu, Gedenser (eastern Ethiopia), and Wereda 10 (Addis Ketema, central Ethiopia). The core objective of the study was to assess issues related to youth unemployment and entrepreneurship in major cities of Addis Ababa and Dire Dawa. Some of the specific objectives set were to determine unemployment rate for male and female youth in the selected Kebele/ Sub city, determine the magnitude/proportion of the unemployed across population subgroups (by specific age bracket, by sex, and by urbanity), and similarly identify major bottlenecks for the female youth and male youth to start up own business in the selected two areas.

As a springboard for conclusion, the following hypotheses were set: the level of female youth unemployment exceeds male youth unemployment, financial constraint is the most critical bottleneck to start up a new business in the selected sites, the youth is suffering from unfair competition and corruptive employment actions, and youth in the area lack training related to starting their own venture. As a tool of descriptive data analysis and presentation, in this study, frequency tables have been utilized in depth. Moreover, binary logistic regression predicting and analysis tool has been used to check the prospect of youth self-employment in the study sites.

The census finding shows that youth unemployment rate is at $11.39 \%$ aggregately for the two project sites. Specifically, the study site at Addis Ababa prevails youth unemployment rate of $10.06 \%$. Contrastly, the two sites in Dire Dawa sites Melka Jebdu and Gedenser have youth unemployment rate of 12.87 and $20.34 \%$ consecutively. In addition, it has found that the major cause of youth not to engage in self-employed job is related to capital financing.

The research has also tried to determine how unemployment is reflected gender wise. Accordingly, the aggregate data shows hypothesizing that unemployment are highly prevail on female than on male in the localities is totally false.

Generally, this paper has investigated issues like factors affecting youth prospect to (Continued on next page)
\end{abstract}


(Continued from previous page)

be self-employed in overall study sites, the involvement of youth in multiple jobs

(employments); it also indicates the degree of influence of various factors on youth

to be self-employed. Finally, this study has provided vital conclusions and policy

recommendations to handle youth's employment/unemployment and

entrepreneurship issue specific to the study areas.

Keywords: Equib, EDiR, CBMS, Self-employed

\section{Background}

Almost $90 \%$ of the world's youth are living in countries where they can hardly access sufficient education, capital, paid employments, and health services. As the sizes of younger populations in Africa steadily swell to account the single largest category of age group, the likelihood of majority of these youth being absorbed within the formal economy is nearly nonexistent (DSW 2011).

Encouraging the integration of young people at work and improving their situation in the labor market are two of the main priorities of the government of Ethiopian (Talent Youth Association (TaYa) 2014).

This hard fact has strong implication on the demographic and socioeconomic reality of Ethiopia. More than half of the population in Ethiopia is made up of young people under the age of 25 (DSW 2011). It is also true that women constitute slightly more than half the population of Ethiopia. Greater numbers of youth and women are vulnerable to conditions which deprive them from securing material welfare. They are mostly engaged in the informal sector to earn income for their day to day life (Central Statistical Agency 2008).

Governmental organizations, NGOs and civic associations in Ethiopia, and other countries adopt and use various age ranges for the concept of "Youth" from the standpoint of the purpose which they stand for and the activities they undertake. For example, the United Nations (UN) and WHO define the youth as persons between 15-24 years and 10-24, respectively. In Ethiopian context, the Ethiopian Social Security and Development Policy define youth as someone between the age ranges of 15-24 years old (Ministry of Youth, Sports and Culture of Ethiopia 2005).

In the context of Ethiopia, all persons aged 10 years and over who were productively engaged or available to be engaged during the reference period were included as economically active persons. In other words, the economically active population comprises all persons aged 10 years and over who were employed or unemployed in the stated period. The complements, i.e., those who were neither engaged nor furnish their labor constitute the economically inactive population (Central Statistical Agency 2005).

The employed population in the current status approach consists of those who were engaged in productive activity for $4 \mathrm{~h}$ or more during the 7 days prior to the date of the interview. Persons who had regular jobs, occupation, or holdings to return to but were absent from work (i.e., not at work or worked less than $4 \mathrm{~h}$ ) for various reasons were also considered as employed (ibid).

The Central Statistical Agency definition of unemployment includes an individual who satisfies the ILO standard definition, and it is also contextualized for Ethiopia by incorporating partially relaxed and completely relaxed options of measurements (ibid). 
The standard definition of unemployment of ILO is based on the following three criteria that must be satisfied simultaneously; "deprived of work," "currently available for duty," and "looking for job." Further, under partial relaxation, the definition of unemployment comprises of discouraged job seekers in addition to persons satisfying the standard definition. Discouraged job seekers are those who want a job but did not take any active step to search for work because they believe that they cannot find one. In case of the completely relaxed definition, unemployment includes persons without work and those who are available for work, including those who were or were not looking for work. That is, the seeking work criterion is completely relaxed and unemployment is based on the "without work" and "availability" condition only (ibid).

Today, of all the effects of the economic crisis, unemployment of young people is one of the most worrying subjects. More than half of the young people aged below 25 who want to work cannot find a job opportunity, and almost 35\% of unemployed young people have been in this situation for over 1 year. Youth employment is a key concern in Ethiopia, as almost two-third of the population is younger than 25 years. Because of fast population growth, the labor force is expected to double in the next 25 years (ibid).

Currently, there are 31 public universities under the administration of ministry of education of Ethiopia. This high number of universities has produced many graduates ready for work. Yet, currently, the most accessible job opportunities involve farming. Eighty percent of Ethiopia's overall labor force is engaged in subsistence farming. Therefore, more job opportunities are critically needed for higher educational institute graduates (Talent Youth Association (TaYa) 2013).

Ethiopia has one of the highest urban unemployment rates worldwide at $50 \%$ of the youth labor force. According to a report by the Ministry of Labor and Social Affairs, 87\% of all registered job seekers are between the ages of 15-29. Sixty eight percent (68\%) of employed youth (rural and urban) are unpaid family workers. Additional assessments of urban youth unemployment include the following: 6\%-15-19 years old, 18\%-2024 years old, and 11\%-15-24 years old (Talent Youth Association (TaYa) 2013).

The lack of employment opportunities for Ethiopian young people is among the critical development challenges facing by the country and a key barrier to national efforts toward the achievement of the Millennium Development Goals (Talent Youth Association (TaYa) 2013).

Thus, to accelerate the growth, security and sustainability of the Ethiopian economy development, each sector needs to be supported by young entrepreneurs and employees. Additionally, the need to create more jobs which is consistent and compatible to new graduates is very essential. Youth unemployment breeds displeasure, hopelessness, and despair. These conditions are more likely to result in youth engaging in risky and destructive behavior. The consequences of youth's risky behavior affect their own health, their families, communities, and the nation at large. Similarly, they might be unproductive, they feel a sense of desperateness, and be at great risk for drug and alcohol addiction, delinquency, and getting involved in crime. This may eventually also lead to social unrest and civil disobedience (Talent Youth Association (TaYa) 2013).

Generally, supporting youth employment can help break the cycle of poverty. It is estimated that creating productive work for young people in sub-Saharan Africa could result in a potential GDP increase of 12-19\% (Talent Youth Association (TaYa) 2013).

Local governments are responsible to create job opportunities for those youth not only in government offices but also in various NGOs and private organizations. Thus, 
it is our duty to utilize the opportunity unless it will be a time bomb blast at one time in future which can completely distract the social, political, and economic stability of the country. Even though it is primarily the government's responsibility to address the issue of unemployment, the society should play their parts in the efforts being taken by the government as they will be the main victims of unemployment which ultimately results in poverty. Meanwhile, the country higher officials need to intensively work on entrepreneurship and job creation for the targeted portion of the society (youth). Though it is not sufficient enough, the Ethiopian government is working hard to open suitable ground for youth entrepreneurship through crafting and implementing a sound policy to bind youth under Small and Micro Enterprises (SMEs).

Finally, it is better to inquire why prevalence of unemployment is high in the country and in the selected Community Based Monitoring System (CBMS) project areas. Is that due to the number of youth and job creation rate is mismatched or any other factors are influencing? And how government is working with entrepreneurship and how youth are benefited from the policy direction needs to be investigated.

The data has been collected from total of 3591 both from Dire Dawa and Addis Ababa. Numerically, the number of youth in Wereda 10, Melka Jebdu, and Gedenser is 2048, 1484, and 59 consecutively.

\section{Methods}

\section{Participants and procedures}

Youth with the age range of 15-24 years old has been taken as a target study. The instruments which have been developed were tested for field validity on 100 targets. Then, the field pilot study has clearly indicated the contents of the instruments in which the researcher has to review. Consequently, some questions have been added and removed. Options or response lists have been updated. After doing this on all the questionnaires, Household Profile Questionnaire (HPQ), Community Profile Questionnaire, and Youth Employment and Entrepreneurship Questionnaire (YEEQ), they have been uploaded to digital format where it become available for tablet based data collection purposes.

Then, the data has been collected using the latest gadget of Samsung tablet 4 equipped with GPRS reading. Every data collected has GPRS readings of latitude, longitude, and altitudes with accuracy of less than 15.

\section{Statistical analysis approach}

The tablet-based data collection approach has eliminated the tiresome data encoding tasks. The data which has been collected and uploaded was downloaded directly from data server and followed by editing. Meanwhile, the researcher has used STATA13 to generate tables and figures.

The binary logit predicting model has been used to identify the pattern of relationship between the prospects of a youth to be an entrepreneur subject to the explanatory variables. To be more detailed and illustrative, marginal effects $(\mathrm{mfx})$ of the explanatory variable to the output variables have been made.

The binary choice model (logistic regression analysis) has assumed dependent variable was the intention or prospect of youth to involve in self-own business in relation 
to the independent or explanatory variables of age, sex, access to various media outlets, social capital, education and etc. Those independent (explanatory variables have been grouped as individual characteristics, household characteristics, and community characteristics. For instance, age, sex, and education level best describe individual characteristics. Household's total asset, household's access to various media outlets (TV, radio, and newspaper) describe the household's characteristics. Meanwhile, membership in cooperative union and equib best explains the impact emanating from community characteristics to affect youth intention to be self-employed.

Below is the logit model used in this study;

$$
\log \left(\frac{p_{i}}{1-p_{i}}\right)=\alpha+\beta I+\theta H+\delta C+e
$$

Where

$\alpha$-vector of coefficient of independent variation

$\beta$-vector coefficient of variables, which indicates individual characteristics

$\theta$-vector coefficient of variables, which indicates household characteristics

$\delta$-vector coefficient of variables, which indicates community level characteristics

$Y$-whether the individual is self-employed or not, i.e., $1=$ self-employed and $0=$ not self-employed

$P_{i}=$ probability of $Y=1$

$I$-vector variables, which indicates individual characteristics

$H$-vector variables, which indicates household characteristics

$C$-vector variables, which indicates community characteristics

$e$-error term

As a complimentary for this analysis, the multicollinearity test based on variance inflation factor (VIF), correction method for heteroskedasticity problem, and specification tests has been done. According to Gujarati (2004), VIF shows how the variance of an estimator is inflated by the presence of multicollinearity. It is defined as $\operatorname{VIF}_{j}=\frac{1}{1-R_{j}^{2}}$ where $R_{j}^{2}$ is the coefficient of determination that is obtained when the continuous explanatory variable is regressed against all the other explanatory variables. When VIF increases with $R_{j}^{2}$, collinearity will increase. According to Gujarati, as a rule of thumb, if the VIF of a variable surpasses 10 , which will happen if $R_{j}^{2}$ exceeds 0.90 , those variables are said to be highly collinear.

The post optimality tests of endogeneity and multicollinear have been made and the mean VIF result is less than 10 .

\section{Instruments and conceptual framework}

This study has been conducted in two separate administrative regions of Ethiopia. The areas are designated as Dire Dawa and Addis Ababa. The study was census-based where enumeration was made on 5620 households consisting 3951 youth.

Mainly three types of questionnaires have been administered: Household Profile Questionnaire, Youth Employment and Entrepreneurship Questionnaire, and Community Profile Questionnaire. The main questionnaire which has been considered and analyzed for this research paper is the Youth Employment and Entrepreneurship. 
This study has avoided the traditional paper and pen-based data enumeration and substituted by tablet-based data collection. This approach helped the researcher to track the GPS location of each and every household and genuine process of the data collection. Totally, the data collection was digital and the data editing was conducted in the same format.

Those H1, H2, and H3 are hypotheses set between corresponding group of factor variables (individual, household, and community) and prospect of youth to involve on entrepreneurial activity. Those hypotheses have been set one by one in the later section (Fig. 1).

\section{Results and discussions}

This part has been sub-classified as descriptive research and inferential model output. In descriptive analysis, frequency tables have been used thoroughly. In the second section, mainly logistic regression analysis has been used to identify the influence of explanatory variables on youth intention to involve on entrepreneurial activity.

\section{Descriptive research outputs}

In this section, tabular analysis and relative frequency measures are used to investigate youth circumstance related to various unemployment and entrepreneurship factors.

All figures generated in this paper are comparative and consider the experience of unemployment and entrepreneurship in rural area and urban area. Those two major cities are known to have prevalence of problems of unemployment. As it has been also depicted at the middle of this paper, the prevalence of unemployment and engagement in entrepreneurial activity varies between urban and rural area of Ethiopia.

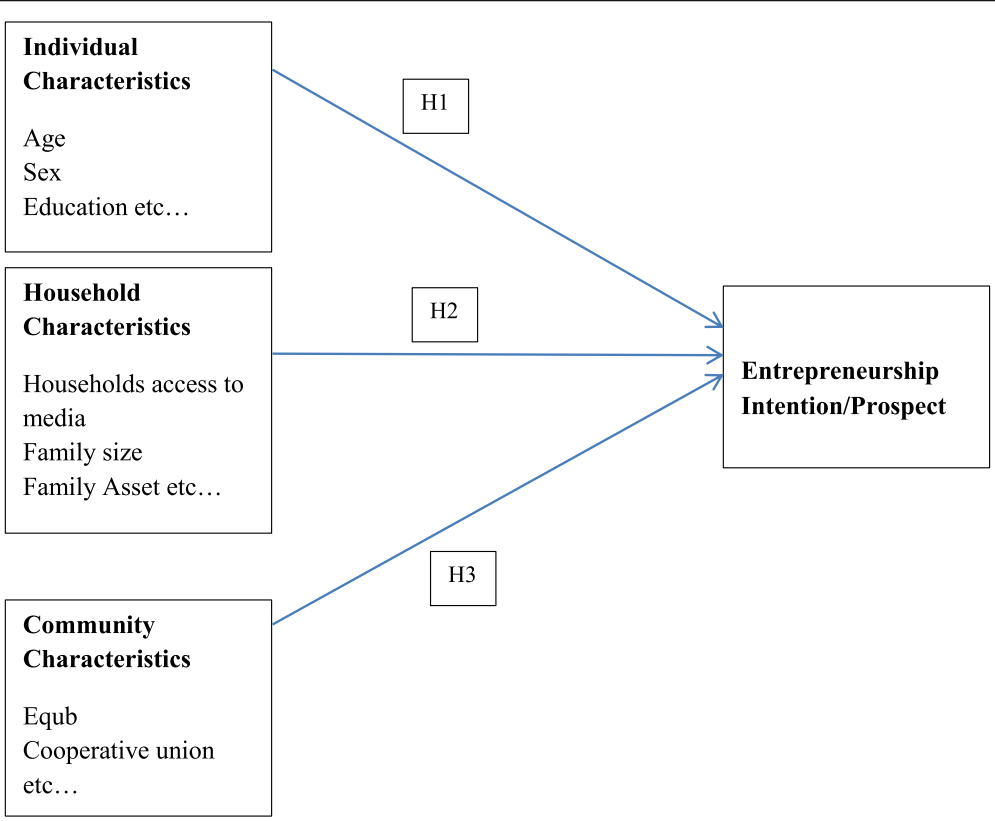

Fig. 1 Conceptual framework 
Table 1, 2, 3, 4, 5, 6, 7, 8, 9, 10, 11 depicts the distribution of unemployed youth in the overall study sites. The enumeration found that in the overall study sites there are 3591 youth. From this, $11.39 \%$ is unemployed while $88.61 \%$ of them are not unemployed. Not unemployed includes employed youth and youth who are not ready to work or not actively searching for a job.

The prevalence of unemployment in Wereda 10 of Addis Ketema as it has been shown above is only $10.06 \%$.

A large proportion of youth unemployment, $12 \%$, is observable in Melka Jebdu area of Dire Dawa. Comparatively, the severity of youth unemployment is high in this particular administrative area.

In Gedenser the rate of unemployment is $20.34 \%$, whereas $79.66 \%$ are accounted as not facing the problem of unemployment.

The above table shows how unemployment is prevailed in relation with gender. Previous tables show that the total number of unemployed from 3591 youth in the overall study site is 409. According to the tabular presentation of Bizuneh et al. (2001), in Ethiopia, the percentage of female unemployment rate is higher than that of male. Similarly, recent study shows specific to urban areas unemployment among women is estimated to be about $27.2 \%$ compared to $13.7 \%$ among men. The same pattern holds true for rural areas, where approximately $4.6 \%$ of women and $0.9 \%$ of men are reported to be unemployed (ILO 2009).

Thus, the following hypotheses were set:

Hypothesis: the level of female youth unemployment exceeds male youth unemployment

The total census survey and table above indicate that in the overall study sites, male youth are highly exposed to unemployment than female youth. Hence, the proposed initial hypothesis that unemployment is high on female than on male is completely false. In figures, this study clearly depicts from the total youth unemployed, $56.48 \%$ are male and $43.52 \%$ are female.

Access to finance is important for the growth of SMEs (Osano and Languitone 2016) and a significant element for determining the growth and survival of SMEs (ACCA 2009). Access to finance enables small businesses to undertake productive investments and contributes to the development of the national economy and alleviation of poverty in most of the Sub-Saharan African countries (Beck and Demirguc-Kunt 2006). Further, access to finance is the most serious barrier to the expansion of businesses and start-ups which have been mentioned by existing SMEs and potential operators (Olomi and Urassa 2008).

Table 1 Youth unemployment status by gender and study sites

\begin{tabular}{|c|c|c|c|c|c|c|}
\hline \multirow[t]{3}{*}{ Site } & \multirow{2}{*}{\multicolumn{2}{|c|}{ Unemployed }} & \multicolumn{4}{|l|}{ Sex } \\
\hline & & & \multicolumn{2}{|l|}{ Male } & \multicolumn{2}{|l|}{ Female } \\
\hline & Magnitude & Proportion & Magnitude & Proportion & Magnitude & Proportion \\
\hline Wereda 10 & 206 & 10.06 & 102 & 49.51 & 104 & 50.49 \\
\hline Gedenser & 12 & 20.34 & 7 & 58.33 & 5 & 41.67 \\
\hline Kebele 01 & 191 & 12.87 & 122 & 63.87 & 69 & 36.13 \\
\hline Total & 409 & 11.39 & 231 & 56.48 & 178 & 43.52 \\
\hline
\end{tabular}


Table 2 Factors affecting to be self-employed

\begin{tabular}{|c|c|c|c|c|c|c|c|c|}
\hline \multirow[t]{2}{*}{ Site $\rightarrow$} & \multicolumn{2}{|l|}{ Wereda 10} & \multicolumn{2}{|l|}{ Gedenser } & \multicolumn{2}{|l|}{ Kebele 01} & \multicolumn{2}{|l|}{ Total } \\
\hline & Magnitude & Proportion & Magnitude & Proportion & Magnitude & Proportion & Magnitude & Proportion \\
\hline $\begin{array}{l}\text { Business } \\
\text { license }\end{array}$ & 30 & 1.46 & 2 & 3.39 & 70 & 4.72 & 102 & 2.84 \\
\hline Capital & 462 & 22.56 & 21 & 35.59 & 799 & 53.84 & 1282 & 35.70 \\
\hline $\begin{array}{l}\text { Market } \\
\text { access }\end{array}$ & 49 & 2.39 & 25 & 42.37 & 89 & 6.00 & 163 & 4.54 \\
\hline $\begin{array}{l}\text { Input } \\
\text { access }\end{array}$ & 26 & 1.27 & 7 & 11.86 & 55 & 3.71 & 88 & 2.45 \\
\hline Other & 1 & 0.05 & 0 & 0.00 & 3 & 0.20 & 4 & 0.11 \\
\hline $\begin{array}{l}\text { Not } \\
\text { applicable }\end{array}$ & 1480 & 72.27 & 4 & 6.78 & 468 & 31.54 & 1952 & 54.36 \\
\hline Total & 2048 & 100.00 & 59 & 100.00 & 1484 & 100.00 & 3591 & 100.00 \\
\hline
\end{tabular}

Source: CBMS-Ethiopia Survey, 2015

Supporting the above literature, the figures set on the table above related to this study indicate capital as the major factor which contributes adversely to youth not to involve in self-employment in the overall study area. As an adverse effect, capital takes 35.70\% of the time as a cause to aggravate youth not to begin their own business. Numerically, almost 1282 of the 3591 youths complain absence of capital as a major factor to influence self-employment.

Similarly, the figures in the same table indicate capital as the major hindering factor for the youth not to be self-employed in Wereda 10 . Almost $22.56 \%$ of the youths complained capital as prominent factor in this area.

Still in Melka Jebdu (Kebele 01), capital persists as the core problem for youth not to involve on self-employed businesses. It takes $53.84 \%$ of the time as hindering and challenging factor.

Note: None in the table above indicates the proportion of youth who do not try to be self-employed at all or who tried but not mentioned factors which adversely affect their effort to be self-employed.

Exceptionally, in Gedenser area, capital is not considered as the factor which challenges those youth who tried to be self-employed. Capital gives way to problem of access to market. With regard to capital, being in rural area, there is enough land and irrigable land. But the major factor is impossibility of market access due to absence of transportation infrastructure. The problem of market access is high at $42.37 \%$.

However, it does not mean that the issue of capital problem is zero. Still, it affects $35.59 \%$ of the time.

Table 3 Youth participation on technical and vocational school and corresponding gender distribution in overall project sites

\begin{tabular}{|c|c|c|c|c|c|c|}
\hline \multirow[t]{3}{*}{ Site } & \multirow{2}{*}{\multicolumn{2}{|c|}{ Participating in TVS }} & \multicolumn{4}{|l|}{ Sex } \\
\hline & & & \multicolumn{2}{|l|}{ Male } & \multicolumn{2}{|l|}{ Female } \\
\hline & Magnitude & Proportion & Magnitude & Proportion & Magnitude & Proportion \\
\hline Wereda 10 & 116 & 5.66 & 66 & 56.90 & 50 & 43.10 \\
\hline Gedenser & 2 & 3.39 & 2 & 100.00 & 0 & 0.00 \\
\hline Kebele 01 & 29 & 1.95 & 23 & 79.31 & 6 & 20.69 \\
\hline Total & 147 & 4.09 & 91 & 61.90 & 56 & 38.10 \\
\hline
\end{tabular}

Source: CBMS-Ethiopia Survey, 2015 
Table 4 Youth involvement on entrepreneurship training

\begin{tabular}{|c|c|c|c|c|}
\hline \multirow[t]{2}{*}{ Site } & \multicolumn{2}{|l|}{ Yes } & \multicolumn{2}{|l|}{ No } \\
\hline & Magnitude & Proportion & Magnitude & Proportion \\
\hline Wereda 10 & 70 & 3.42 & 1978 & 96.58 \\
\hline Gedenser & 14 & 23.73 & 45 & 76.27 \\
\hline Kebele 01 & 315 & 21.23 & 1169 & 78.77 \\
\hline Total & 399 & 11.11 & 3192 & 88.89 \\
\hline
\end{tabular}

Source: CBMS-Ethiopia Survey, 2015

Financial constraints such as inadequate investment capital, insufficient loan, and inefficient financial market are the major obstacles in doing business, and most MSE's are highly risky ventures involving excessive administrative costs and lack of experience in dealing with financial institutions (Commission on Legal Empowerment of the Poor (CLEP) 2006).

Access to finance is the most serious barrier for expansion of businesses and startups which have been mentioned by existing SMEs and potential operators (Olomi and Urassa 2008). Hence, one of the hypotheses was set as follows:

Hypothesis: financial constraint is the most critical bottleneck to start up a new business in the selected sites

This study, which is made on the youth, has confirmed that capital (financing) takes the lion's share of the major critical problems which threatens youth not be successful in establishing own business firms. Hence, the table above has granted logical reason to conclude that capital is the major factor that hinders youth not to establish and be successful in self-business. The alternative tiny source of capital which is currently available is to involve in equib, i.e., traditional and voluntary saving. But this one contributes little for the required paid-up capital. In Ethiopia, Technical and Vocational School (TVS) training is an option for youth to make them ready for future career. Totally, in the study sites, $95.91 \%$ of the total youth did not participate in technical and vocational school. But specific observations depict that in Wereda $10,94.34 \%$ of the youth has participated in technical and vocational school, numerically, that is 147 youth. In Melka Jebdu, the experience is like Wereda 10 where majority does not go through technical and vocational training. In contrast, only $1.95 \%$ has attended this program. In the other study site, Gedenser, the participation of youth in technical and vocational school is only $3.39 \%$ where majority (96.61\%) are out of the training program.

Entrepreneurship training includes business plan formulation. Literature scrutinized reveals that entrepreneurs need to engage in planning, as new ventures experience significant difficulties in finding a viable business model, and they often need to adapt their initial business plans (Andries and Debackere 2007). Woods and Joyce (2003)

Table 5 Youth employment status and gender in overall project sites

\begin{tabular}{|c|c|c|c|c|c|c|}
\hline \multirow[t]{3}{*}{ Site } & \multirow{2}{*}{\multicolumn{2}{|c|}{ Employed }} & \multicolumn{4}{|l|}{ Gender } \\
\hline & & & \multicolumn{2}{|l|}{ Male } & \multicolumn{2}{|l|}{ Female } \\
\hline & Magnitude & Proportion & Magnitude & Proportion & Magnitude & Proportion \\
\hline Wereda 10 & 1117 & 54.54 & 464 & 41.54 & 653 & 58.46 \\
\hline Gedenser & 10 & 16.95 & 1 & 10.00 & 9 & 90.00 \\
\hline Kebele 01 & 102 & 6.87 & 47 & 46.08 & 55 & 53.92 \\
\hline Total & 1229 & 34.22 & 512 & 41.66 & 717 & 58.34 \\
\hline
\end{tabular}

Source: CBMS-Ethiopia Survey, 2015 
Table 6 Employed youth involvement in extra job (multiple employment)

\begin{tabular}{|c|c|c|c|c|}
\hline \multirow[t]{2}{*}{ Site } & \multicolumn{2}{|l|}{ Involved } & \multicolumn{2}{|c|}{ Not involved } \\
\hline & Magnitude & Proportion & Magnitude & Proportion \\
\hline Wereda 10 & 62 & 5.55 & 1055 & 94.45 \\
\hline Gedenser & 0 & 0.00 & 10 & 100.00 \\
\hline Kebele 01 & 1 & 0.98 & 101 & 99.02 \\
\hline Total & 63 & 5.13 & 1166 & 94.87 \\
\hline
\end{tabular}

Source: CBMS-Ethiopia Survey, 2015

found that those firms that were growing fast used more planning tools than those that were not, and declining firms used the fewest. Nonetheless, there is also a need to provide training to improve the chances of business success. A lack of knowledge is the obstacle in using planning tools rather than the value that small firm managers place on a tool that they have not heard about (Woods and Joyce 2003).

Accordingly, one of the pull factors which stimulate youth to be self-employed is participation in entrepreneurial training. Considering this fact, from the total 3591 youths of the study sites, only $11.11 \%$ have participated in entrepreneurial training. However, $88.89 \%$ had no related training at all.

Hypothesis: youth in the area lack training related to starting own venture According to the above table or finding, majority of the youth (88.89\%) in the whole project sites does not have entrepreneurship training. Additionally, 95.91\% of the youth does not pass through technical and vocational schools from where youth could learn various technical skills. Hence, conditions are sufficient to conclude that youth in the area lacks training related to starting their own venture.

As far as youth employment is concerned, almost $34.22 \%$ of youth in the overall project site is employed. Employed means they are either self-employed or employed somewhere for wage or salary.

When the issue of employment is decomposed at Kebele or Wereda level, in Wereda 10 , still, a significant number of the youth population are not employed, i.e., at $45.46 \%$ employed, figure shows only 54.54\%.

In Kebele 01, Dire Dawa, the number of youth is 1484 . Of which, only $6.87 \%$ are employed (self-employed or employed for wage/salary or family gain, etc.). The severity of the problem of being not employed is high in this study site. Whereas, in Gedenser, $16.95 \%$ of the youth are employed.

Table 7 Youth self-employment status and sex in overall project sites

\begin{tabular}{|c|c|c|c|c|c|c|}
\hline \multirow[t]{3}{*}{ Site } & \multirow{2}{*}{\multicolumn{2}{|c|}{ Self-employed }} & \multicolumn{4}{|l|}{ Sex } \\
\hline & & & \multicolumn{2}{|l|}{ Male } & \multicolumn{2}{|l|}{ Female } \\
\hline & Magnitude & Proportion & Magnitude & Proportion & Magnitude & Proportion \\
\hline Wereda 10 & 59 & 2.88 & 35 & 59.32 & 24 & 40.68 \\
\hline Gedenser & 0 & 0 & 0 & 0 & 0 & 0 \\
\hline Kebele 01 & 3 & 0.20 & 1 & 33.33 & 2 & 66.67 \\
\hline Total & 62 & 1.73 & 36 & 58.06 & 26 & 41.94 \\
\hline
\end{tabular}

Source: CBMS-Ethiopia Survey, 2015 


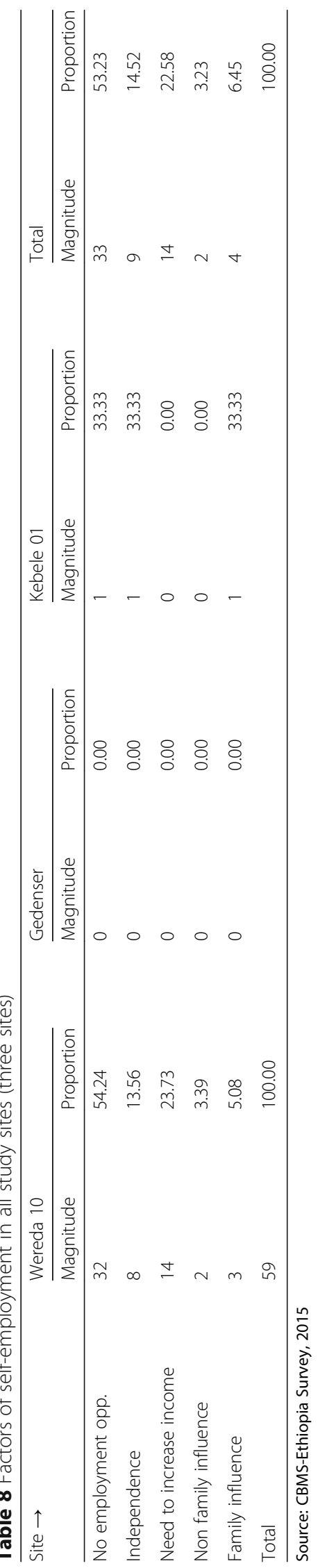


Table 9 Unemployment and unfair competition

\begin{tabular}{|c|c|c|c|c|}
\hline \multirow[t]{2}{*}{ Site } & \multicolumn{2}{|l|}{ Bribed } & \multicolumn{2}{|l|}{ Not bribed } \\
\hline & Magnitude & Proportion & Magnitude & Proportion \\
\hline Wereda 10 & 5 & 2.43 & 201 & 97.75 \\
\hline Gedenser & 0 & 0.00 & 12 & 100.00 \\
\hline Kebele 01 & 19 & 9.95 & 172 & 90.05 \\
\hline Total & 24 & 5.87 & 385 & 94.13 \\
\hline
\end{tabular}

Source: CBMS-Ethiopia Survey, 2015

Youth might involve in multiple jobs in a regular or part-time basis. The overall project site observation shows, out of total employed youth of 1229 , that only $5.13 \%$ have multiple jobs or duties. However, $94.87 \%$ are with no extra job.

In Wereda 10, 1117 youth are employed and out of that, 7.77\% are working with extra duty. Still, $94.45 \%$ are limited in a single job.

In Melka Jebdu, out of the entire youth, only 102 are employed. Even out of those 102 employed youth, only $0.98 \%$ has engaged in multiple jobs.

In the other subproject site in Gedenser, Dire Dawa, there is no observation with employment and extra duty engagement.

Hypothesis: many youth especially those with lower educational attainment venture into entrepreneurial activity out of necessity

Table 10 Logistic regression result for covariates of self-employment

\begin{tabular}{llll}
\hline Variable description & Variable name & Coefficient & Robust standard error \\
\hline Age of the youth & age_yr & 0.26 & $0.065^{c}$ \\
Sex of the youth & Sex & -0.53 & $0.28^{\mathrm{a}}$ \\
Educational status of the youth & Educal & -0.18 & $0.056^{c}$ \\
Television ownership of the youth's family & Tv & 0.015 & 0.36 \\
Radio ownership of the youth's family & Radio & 0.16 & 0.27 \\
Telecommunication access of the youth & Telecomind & 3.33 & $1.07^{c}$ \\
Newspaper access for the youth & Nwsppraccess & -0.51 & $0.29^{\mathrm{a}}$ \\
Equib membership of the youth & Equibind & 1.18 & $0.312^{c}$ \\
Cooperative membership of the youth & Coopind & -1.38 & $0.73^{\mathrm{a}}$ \\
Total asset value of the youth's family & total_asset & 0.0001 & 0.0001 \\
Family size of the youth's family & family_size & -0.06 & 0.06 \\
Technical or vocational training received & Tvs & -0.404 & 0.53 \\
Entrepreneurship training received & entrep_te & -0.708 & 0.060 \\
& constant & -10.9 & $1.86^{c}$ \\
Number of Observation & & 3591 & \\
Wald chi ${ }^{2}(13)$ & & $85.69^{c}$ & \\
Prob > chi2 & & 0.0000 & \\
Pseudo $R^{2}$ & & 0.2375 & \\
\hline
\end{tabular}

${ }^{\mathrm{a}}$ Significant at $10 \%$

${ }^{\mathrm{b}}$ Significant at $5 \%$

'Significant at $1 \%$

Source: CBMS-Ethiopia Survey, 2015 
Table 11 Marginal effect for covariates of self-employment

\begin{tabular}{lcc}
\hline Variable description & Dy/dx & SE \\
\hline Age of the youth & 0.0008341 & 0.00038 \\
Sex of the youth & -0.0016758 & 0.00087 \\
Educational status of the youth & -0.0005793 & 0.00021 \\
Television ownership of the youth's family $^{a}$ & 0.000483 & 0.00113 \\
Radio ownership of the youth's family $^{a}$ & 0.0004956 & 0.00083 \\
Telecommunication access of the youth $^{\mathrm{a}}$ & 0.0070345 & 0.00226 \\
Newspaper access for the youth $^{\mathrm{a}}$ & -0.0014629 & 0.00089 \\
Equib membership of the youth $^{\mathrm{a}}$ & 0.0062029 & 0.00313 \\
Cooperative membership of the youth $^{\text {Total asset value of the youth's family }}{ }^{\mathrm{a}}$ & -0.002679 & 0.00126 \\
Family size of the youth's family $^{\mathrm{a}}$ & $2.01 \mathrm{e}-09$ & 0.00000 \\
Technical or vocational training received $^{\mathrm{a}}$ & -0.0001888 & 0.00019 \\
Entrepreneurship training received $^{\mathrm{a}}$ & -0.0010679 & 0.00122 \\
\hline
\end{tabular}

${ }^{a} \mathrm{dy} / \mathrm{dx}$ is for discrete change of dummy variables from 0 to 1

The above table confirms that majority of youth in the area joins self-business out of necessity because $94.87 \%$ of employed youth does not have extra job. It has involved in the self-business for necessity purpose.

In Ethiopia, 54.8\% of the self-employed in both urban and rural areas were male, and the survey results indicate that paid employment is dominated by males (NLFS 2005). Age can be an important factor in entrepreneurial intention (prospect). Research shows that people mostly decide to establish their own firm between the age of 25 and 45 years old (Storey 1994). This tendency specially increases between the ages of 25 and 34 (Delmar and Davidson 2000).

Though literatures indicate that being youth has high tendency to involve in self-business, the finding in the above table or this study depicts only $1.73 \%$ of the youth owns or involved in self-business. However, 98.27\% are either employed for wage/salary or jobless. Specifically, $2.88 \%$ of youth in Wereda 10 are self-employed, while $97.12 \%$ of them are either employed for wage or simply jobless.

While in Melka Jebdu (Kebele 01), the problem of being not self-employed is extremely high with the proportion or percentage of 99.80. It is daring to say almost no one is self-employed.

The above table shows there is no self-employment in Gedenser rural Kebele of Dire

Dawa. Previous tables show that the youth of Gedenser are totally not self-employed or employed for wage/salary.

Youth might raise various reasons for being self-employed. The table above shows why youth prefer to be self-employed. As per the analysis result in the table above, the major factor which influences the youth to be dared of self-employment is the absence of employment opportunity. This also complies with youth engagement on selfbusiness out of necessity. Youth will prefer to start their own business if they are jobless for a long period of time. In addition, so as to generate higher amount of income, youth might join self-business. 
Employment services in Ethiopia are too weak to provide even basic services such as information to jobseekers and employers. They have not been able to comply with the changing requirements of the labor market. In addition, many jobs in Ethiopia are in the informal economy and, by definition, the vacancies are not documented or registered with the Public Employment Services. Informal mechanisms such as personal networks have been common ways of recruitment in Ethiopia (Kibru 2012).

Based on the literature above, the study initially set the following hypothesis:

Hypothesis: the youth is suffering from unfair competition and corruptive employment actions

The table above indicates that $5.87 \%$ of the unemployed youth confirmed that the employment environment is highly unfair. Hence, it is true that the youth is suffering from unfair competition and corruptive employment actions.

\section{Model results and discussion}

\section{Covariates of self-employment (engagement in entrepreneurship)}

In this section, effort is made to identify the correlates of self-employment in order to make the determinants of entrepreneurship engagement analysis complete. The simplest way to analyze the correlates of self-employment is using a logistic regression analysis of whether the youth is engaged in entrepreneurship against household demographic factors, specific individual characteristics, asset holdings of the household, village-level factors, social capital indicators, and policy-related variables. Based on this rationale, the model is specified as follows.

\section{Model specification}

The dependent variable represents the engagement of the youth in entrepreneurial activity. To identify the correlates of this engagement, binary variable that indicates involvement in entrepreneurial activity is regress up against different covariates of this engagement in logistic regression. Denoting all explanatory variables as $X_{i}$, the following equation specifies the model used in this section.

Engage in Entrepreneurship $=\beta^{\prime} X_{i}+\varepsilon_{i}$

Left-hand side term of Eq. (6) is a dichotomy variable which has a value of 1 if the youth is engaged in own business and 0 otherwise. And the right-hand side values in the equation or explanatory variables are (a) household characteristics and demographic variables like sex, age, and years of education of the youth; (b) family background variables like total asset of his/her family, television, and radio access, and family size; (c) social capital variable like engagement in village-level saving and loan association, locally called "equib," and membership for village-level cooperatives; (d) access variables like telecom service accessibility, television, radio, and newspapers' accessibility of youths are considered, and (e) training exposure variables like whether the youth took entrepreneurship shortterm training or short- or long-term training from technical and vocational school is the variable involved in this regression analysis.

The partial correlation coefficient, $\beta$, tells us the association between entrepreneurship engagement indicator and the explanatory variables rather than their 
causal relationship. The detail list of explanatory variable and their description is presented as follows:

$x_{1}=$ age of the youth .

$x_{2}=$ sex of the youth (Dummy); 1 if male and 0 if female.

$x_{3}=$ educational years of the youth.

$x_{4}=$ television ownership of the youth's family (Dummy); 1 if they possess and 0 if not.

$x_{5}=$ radio ownership of the youth's family (Dummy); 1 if male and 0 if otherwise.

$x_{6}=$ telecommunication access of the youth (Dummy); 1 if they have access and

0 if not.

$x_{7}=$ newspaper access of the youth (Dummy); 1 if they have access and 0 if not.

$x_{8}=$ equib membership of the youth (Dummy); 1 if the youth is a member and 0 if not.

$x_{9}=$ cooperative membership of the youth (Dummy); 1 if the youth is member and

0 if not.

$x_{10}=$ total asset value of the youth's family in Ethiopian Birr.

$x_{11}=$ family size of the youth's family.

$x_{12}=$ technical or vocational training received (Dummy); 1 if the youth received

training and 0 if otherwise.

$x_{13}=$ entrepreneurship training received (Dummy); 1 if the youth received training and

0 if otherwise.

\section{Hypotheses of the logistic regression model}

The explanatory variables which are encompassed in the model are based on the expectation or hypotheses which are summarized hereunder.

\section{Age of youth $\left(x_{1}\right)$}

Research shows that people mostly decide to establish their own firm between the age of 25 and 45 years old (Storey 1994). This tendency specially increases between the ages of 25 and 34 (Delmar and Davidson 2000). The larger the age of youth is the better experience for different economic activities. Accordingly, the expectation of this study on the coefficient of age of youth was a positive sign.

\section{Sex of household head $\left(x_{2}\right)$}

In literatures, it is argued that females are less likely to establish their own business than men (Phan et al. 2002; Verheul et al. 2005).

Because of the long trend of educational practices in the country, female are very few in moving up on the ladder of formal education that makes majority of them keen to involve in their own business. Since female youth are considered as a base in the specification, negative sign is expected from the coefficient of this dummy variable.

\section{Years of education of the youth $\left(x_{3}\right)$}

Some argue that education has a positive impact on employment (Bates 1995) whereas others find negative relationship and disagree with this preposition (Reynolds 1995).

Based on the assumption, the more youth is educated the higher the readiness to receive employment from Government Organizations (GOs) and NonGovernment Organizations (NGOs) operate in the country rather than involving 
in their own business, consequently, a negative sign is expected from this variable's coefficient.

Access variables: television ownership of the youth's family $\left(x_{4}\right)$, radio ownership of the youth's family $\left(x_{5}\right)$, telecommunication access of the youth $\left(x_{6}\right)$, and newspaper access of the youth $\left(x_{7}\right)$

Youth who have access to these information sources are empowered by the information and share the experiences of successful entrepreneurs. This is expected to inspire the youth to have their own business or to be engaged in entrepreneurial activities. These variables are expected to contribute positively to entrepreneurial engagement. Hence, positive coefficient is expected.

Equib membership of the youth $\left(x_{8}\right)$ and cooperative membership of the youth $\left(x_{9}\right)$

These social capital indicator and microcredit service variables expected to contribute positively for the youth to be self-employed or to create their own business. Since they are substitute for the formal financial institutes, which marginalize the poor and youth who cannot afford a strong collateral requirement, a positive sign is expected from their coefficient estimates.

The following literature supports the above hypothesis: the access to resources is possible because of the development of social networks (Aldrich and Zimmer 1986). Social connections are the potentially most valuable relationships that an entrepreneur or the entrepreneurial team holds: they help not only to identify business opportunities and attract human and financial resources but also to gain legitimacy (Lechner and Dowling 2003; Stam 2010).

\section{Total asset value of the youth's family in Ethiopian Birr $\left(x_{10}\right)$}

With the assumption that households who possess larger land and other assets can produce better for rural households and can have a better capital for businesses in urban areas and consequently enhance the family income and consumption, these family assets will have a multiplier effect on their young children to get start-up capital. Therefore, a positive coefficient is expected from this variable.

\section{Family size of the youth's family $\left(x_{11}\right)$}

No theoretical and empirical bases were found to expect the sign of this variable's coefficient. So, no sign expectation is set regarding this variable.

\section{Technical or vocational training received $\left(x_{12}\right)$ and Entrepreneurship training received $\left(x_{13}\right)$} Learning important entrepreneurial skills and competencies will lead to perceiving new feasible venture by students, thus affect perceived behavioral control (PBC) (Krueger et al. 2000; Zhao et al. 2005). Second, research found positive relationship between social desirability and entrepreneurship career intention (Tkachev and Kolvereid 1999).

The major objective of such training is to create individuals who can use the available theory and practice in the science of entrepreneurship together with different technical and vocational training skills to engage in their self-employed business. These trainings expected to enhance a person's probability to engage in entrepreneurship activities. Therefore, a positive sign is expected from both variables' coefficients. 


\section{Meanwhile, all aforesaid hypotheses are tested and the result is presented below}

The regression model estimates are presented below in Table 10, and it indicates that the overall model, $\mathrm{chi}^{2}$ calculated, is significant at less than $1 \%$ level of significance. This indicates that the variables which are included in the logistic regression model have coefficients which are jointly different from zero value. In addition, the regression estimate has made with an option of robust standard error rather than the normal one, heteroskedasticity is not a problem anymore. The related multicollinearity test also performed using variance inflation factor (VIF).

In the empirical result with 4.03 average values of VIF, there is no severe multicollinearity among the explanatory variables. All of them have the value less than three, with the exception age of youth.

Most of the coefficients of the explanatory variables have similar signs as it has been expected (hypothesized). With the exception of access to newspaper, cooperative membership of the youth, and entrepreneurship trainings, other variables which are included in the model, viz, age of youth, sex of youth educational status, television, radio and telecommunication access, and equib membership, total asset comes up with the expected sign despite some of them are non-significant as it is observed from Table 10 .

Age can be an important factor in entrepreneurial intention (prospect). Research shows that people mostly decide to establish their own firm between the age of 25 and 45 years old (Storey 1994). This tendency specially increases between the ages of 25 and 34 (Delmar and Davidson 2000). From the table, as it was hypothesized, the variable age level of the youth has positive and highly significant (with $p$ value less than $1 \%$ level) contribution for the youth to engage in self-employment.

Demographic factors such as age and gender have been proposed to have an impact on entrepreneurial intention (prospect) (Kristiansen and Nurul 2004). In literatures, it is argued that females are less likely to establish their own business than men (Phan et al. 2002; Verheul et al. 2005).

Similarly, the logit output in this study found that variable indicated as sex of the youth shows the expected sign and it is also significant at less than $10 \%$. This indicates that there is significant partial correlation between being female and engagement in self-employment.

The logit result specific to the study area confirms similar result. Being male/female has positive relation with the prospect to be an entrepreneur. This will be reinforced by the number of female entrepreneurs that is lower than that of male entrepreneurs in almost every country in terms of Total Entrepreneurial Activity, except Ghana, Costa Rica, and Australia (Kelley et al. 2010). Research provides convincing evidence that the concept of entrepreneurial activity is gender biased: entrepreneurship is often depicted as a form of masculinity, and the terms "entrepreneur" and "male" have tended to become interchangeable (Ahl and Marlow 2012; Gupta et al. 2009).

In addition, empirical studies also focused on individual background characteristics such as education, prior employment experience, and parental role models to explain entrepreneurship intention (Kristiansen and Nurul 2004). There are contradictory findings on education level and entrepreneurial activity. Some argue that education has a positive impact on employment (Bates 1995) whereas others find negative relationship and disagree with this preposition (Reynolds 1995). It can be argued that for people 
with lower education achievement, the only option could be self-employment. In other words, their chance of getting into an organization as paid employee is less. On the other hand, people with higher education have better chances for success both as an entrepreneur and waged employee (Davidson 1995). In this study, the other variable, years of education, come up with the expected negative sign and highly significant result, with $p$ value less than $1 \%$, as it was hypothesized. The coefficient sign of education (negative) implied that the higher the education achievement of the youth the less will be the tendency him/her to involve on self-employment activities. Most of youth who achieves higher level of education are not willing to take risk of involving in entrepreneurial activities. This also better supports youths who are involved if and only if they do not have higher level of education and chance of employment.

The study of Potter (2008) highlighted the function of entrepreneurship education is vital in enhancing the entrepreneurship attitudes of individuals at tertiary level of education. Consequently, entrepreneurship education initiatives at university level are considered vital for increasing potential entrepreneur supply by making more students conscious and interested choosing entrepreneurship as a career option. First, entrepreneurship education helps the students to learn and identify new business opportunities. Such knowledge leads to enhance the number and innovativeness of opportunities which are linked with the technology (Shepherd and DeTienne 2005). Learning vital entrepreneurial skills and competencies will lead to perceive new feasible venture by students, thus affect PBC (Krueger et al. 2000; Zhao et al. 2005). Second, research found positive association between social desirability and entrepreneurship career intention (Tkachev and Kolvereid 1999). While the important role of education is counted in socializing individuals into entrepreneurial careers (Krueger and Brazeal 1994) which can form attitude toward behavior and social norms.

Formal entrepreneurial education provides student experience of mastery, role models, social persuasion, and support by involving them in hands-on learning activities, business plan development, and running simulated or real small business (Fiet 2000; Segal, Borgia \& Schoenfeld 2005). In this study, technical or vocational training (tvs) received and entrepreneurship training received (entrep_te) are the variables considered as areas of entrepreneurial education. Entrepreneurial education mainly motivates and capacitates youth to be self-employed. Though literatures signify the vitality and positive relationship between entrepreneurship training and the entrepreneurial intention of the youth, the result of this study is quite the reverse.

In this study, some variables like access to information show consistent and the rest show contrary result from previously hypothesized coefficient sign. Access to telecommunication services has high, significant, and positive contribution, even less than $1 \% p$ value, for a youth to engage in entrepreneurship. However, television and radio access have no significant contribution for the youth to engage in entrepreneurial activity. On the contrary, those youth who have access for newspaper found that there is a lower probability of youth to engage in his/her own businesses. Empirical review shows that most of Ethiopian newspapers are overwhelmingly crowded with vacancy announcements. Having an exposure to that newspaper will shape youths' intention to be employed than self-employed.

The access to resources is possible because of the development of social networks (Aldrich and Zimmer 1986). Social networks are the potentially most valuable 
relationships that an entrepreneur or the entrepreneurial team holds: they help not only to identify business opportunities and attract human and financial resources but also to gain legitimacy (Lechner and Dowling 2003; Stam 2010).

The value of social networks can be summarized under the concept of social capital theory that is "used to describe the instrumental benefits of social relationships" (Aldrich and Martinez 2001, p.47). Social capital is defined as "resources embedded in a social structure which are or accessed and/or mobilized in purposive action" (Lin 1999, p.35). Social capital is created through investment in social relationships, leading to the creation of socially embedded resources that can be mobilized by individuals (Lin 1999). Social capital allows therefore to achieve objectives that were otherwise difficult to obtain based on the assumption that the social resources of entrepreneurs are more important than the possession of personal resources (Lin 1999).

Similarly and supporting the above literatures, this study confirms social capital variable, equib membership, coefficient is significant and positive as it was hypothesized. It is due to a dual purpose that equib plays in Ethiopia's various villages in both at rural and urban. In the one hand, it substitutes formal financial institutes by providing of microcredit services without collateral requirement to finance members businesses or to start up a new one. On the other hand, it creates a good platform to share experiences of different business persons. Both reinforce the logic behind the positive and significant variable's coefficient. On the contrary, membership in local cooperative has no impact on probability of being self-employed. It may emanate from a very limited human and financial capacities of majority of cooperatives operate in Ethiopia.

All other variables, viz, asset ownership of families of youths, family size, and shortterm entrepreneurship and technical and vocational training from technical and vocational colleges, found to be non-significant.

Variable that indicates urban rural dwellership is automatically dropped by STATA due to its functional multicollinear relationship with other explanatory variables. This has been indicated by STATA output attached in the annex.

The table above indicates marginal effect of the variables (individual, households, and community) on youths' possibility to be self-employed. A percentage increase in educational status reduces the youth possibility to be self-employed by $0.05 \%$. Similarly a percentage increase in youths' access to telecom service increases youths' possibility to be self-employed by $0.7 \%$.

The likelihood of the youth to involve in self-employment positively changes by $0.62 \%$ when the youth decided to participate in equib.

The basic limitation of this study are: first, the study cannot able us to make generalization about the whole youth in Ethiopia. Since the study has collected data from limited households.

Second, the researcher does not think that those are the only variables to affect youth entrepreneurial prospect. Hence, future researchers are anticipated to investigate for other factors which have an impact on the youth prospect to be an entrepreneur.

Third, it will be good if the study were using structural equation model (SEM) than logit model because SEM will show both the paths of effects and degree of impact. The research has an intention to use this model. 


\section{Conclusions and implications}

First, this research has identified in the three sites there is a strong relationship between educational status and the possibility to be self-employed. High achievement in a formal education has negative correlation with the prospect of a person to be self-employed. Empirical evidences also show that a person who reaches graduate level has fear of risktaking and prefers to be salaried than involving in self-employment.

Second, this study has identified social capital variable, equib membership, has direct and strong relationship with the chance of the youth to involve in entrepreneurial activity. The more he or she involved in equib or EDiR which are the communal or village-based savings, the higher the possibility to be an entrepreneur.

Third, age level of the youth has strong relationship with the possibility to be an entrepreneur. The logit result shows the older the age of the youth the higher to involve in entrepreneurial activities.

Meanwhile, the study has the following implications:

Implication number 1: supporting village level association to strengthen: This enhances a chance for a better development for entrepreneurial activity in the study area. Therefore, policies should be designed in such a way to support and give priority to reach the unbanked society.

Implication number 2: communication outlet: Model analysis implies there is a positive relationship between having access to communication media and selfemployment. Hence, it is advised to work in this area (to make youth access media easily) to increase future youth self-employment. The realty on the ground implies still effort is needed to do so. Particularly, access to market information matters to have courage to be self-employed.

Implication number 3: reforming the education system: improve the quality of teaching and learning at school; for instance, curriculum changes toward a more practical orientation, teacher training, infrastructural improvements, and greater public investment in primary and secondary education.

Implication number 4: age has strong impact on the tendency of an individual to be an entrepreneur. This has been clearly indicated by literatures cited in this study. Particularly, supporting the literatures, this study concludes entrepreneurial capacity depreciates with age increment. This totally implies working on youth will have high return than working on other age levels.

\section{Acknowledgements}

It is our pleasure to express gratitude to De La Salle University (DLSU) for their support by providing necessary fund to implement the CBMS project in Ethiopia. Next, we would like to thank Dr. Celia M. Reyes and the CBMS international network research team for their relentless effort in visualization the Community-Based Training Program in Ethiopia. They were part of it since the inception of the project proposal and were not tired of providing supportive comments to improve our research project outputs till today. Special gratitude goes to Novee Lor Leyso and Steffie Joy Calubyan for their long-lasting effort of editing the questionnaires and guiding our team on the CBMS tablet scan process and the commencement of data collection.

Funding

This study has been sponsored by De La Salle University (DLSU). Also, staffs of the funding institution have provided technical support or training on digital data collection and analysis. 
Author Details

Abel Tewolde is a lecturer and researcher at Arsi University, and Christian Feleke is a lecturer and researcher at Haramaya University

\section{Publisher's Note}

Springer Nature remains neutral with regard to jurisdictional claims in published maps and institutional affiliations.

\section{Author details}

${ }^{1}$ Arsi University, Asella, Ethiopia, P.O. Box:193, Asella, Ethiopia. ${ }^{2}$ Haramaya University, Dire Dawa, Ethiopia.

Received: 23 November 2016 Accepted: 28 March 2017

Published online: 27 April 2017

\section{References}

ACCA. (2009). Access to finance for small and medium enterprises sector: the evidence and the conclusion.

Ahl, H., \& Marlow, S. (2012). Exploring the dynamics of gender, feminism and entrepreneurship: advancing debate to escape a dead end? Organization Science, 19(5), 543-562.

Aldrich, H. E., \& Martinez, M. A. (2001). Many are called, but few are chosen: An evolutionary perspective for the study of entrepreneurship. Entrepreneurship Theory and Practice, 25(4), 41-56.

Aldrich, H., \& Zimmer, C. (1986). Entrepreneurship through social networks. In R. Smilor \& D. Sexton (Eds.), The art and science of entrepreneurship (pp. 3-23). New York: Ballinger.

Andries, P., \& Debackere, K. (2007). Adaptation and performance in new businesses: understanding the moderating effects of independence and industry". Small Business Economics, 29(1/2), 81-99.

Bates, T. (1995). Self-employment entry across industry groups. Journal of Business Venturing, 10, 143-I 56.

Beck, T., \& Demirguc-Kunt, A. (2006). Small-medium enterprise sector: access to finance as a growth constraint. Journal of Finance and Banking, 30(11), 2931-2943.

Bizuneh, G., Adino, T. Gesano, G. Guarneri, A. \& Heins, F. (2001). Work status and unemployment in urban Ethiopia. Central Statistical Authority (CSA), Addis Ababa: Ethiopia \& Institute for Population Research - National Research Council (Irp-Cnr), Roma: Italy.

Central Statistical Agency. (2008). Summary and statistical report of the 2007 population and housing census results: Population size by age and sex. Addis Ababa.

Central Statstical Agency. (2005). Census report. http://www.csa.gov.et/images/documents/surveys/Employment_ Unemployment_Survey/Employment_Unemployment_Survey_2004/survey0/data/docs/Pdf/report/summaryreport. pdf. Accessed 15 Mar 2014.

Commission on Legal Empowerment of the Poor (CLEP). (2006). Legal empowerment of the Poor: Entrepreneurship. Background issue paper.

Davidson, P. (1995). Entrepreneurship - and after? A study of growth willingness in small firms. Journal of Business Venturing, 4, 211-226.

Delmar, F., \& Davidson, P. (2000). Where do they come from? Prevalence and characteristics of nascent entrepreneurs, Entrepreneurship and regional development, 12, 1-23.

DSW Ethiopia Brief. (2011). Leavening destitution through decent works:Economic empowerment for poor and the powerless (Vol. 7). http://www.dswethiopia.org. Accessed 17 Jan 2014

Fiet, J. (2000). The Theoretical Side of Teaching Entrepreneur Ship. Journal of Business Venturinglin, 16, 1-24

Gujarati, D. N. (2004). Basic econometrics (4th ed.). New York: The McGraw - Hill Companies.

Gupta, V. K., Turban, D. B., Wasti, S. A., \& Sikdar, A. (2009). The role of gender stereotypes in perceptions of entrepreneurs and intentions to become an entrepreneur. Entrepreneurship Theory and Practice, 33(2), 397-417.

ILO. (2009). http://www.ilo.org/public/english/employment/ent/coop/africa/countries/eastafrica/ethiopia.htm

Kelley, D., Bosma, N., \& Amoros, J. E. (2010). Global entrepreneurship monitor 2010 global report. Babson College,Universidad del Desarrollo and London Business School.

Kibru, M. (2012). EMployement Challenges in Ethiopia. Addis Ababa: Addis Ababa University, Ethiopia.

Kristiansen, S., \& Nurul, I. (2004). Entrepreneurial Intentions among Indonesian and Norwegian Students. Journal of Enterprising Culture, 12(1), 55-78.

Krueger, N. F., Jr., \& Brazeal, D. V. (1994). Entrepreneurial Potential and Potential Entrepreneurs. Entrepreneurship Theory \& Practice, 18(3), 91-104

Krueger, N. F., Jr., Reilly, M. D., \& Carsrud, A. L. (2000). Competing Models of Entrepreneurial Intentions. Journal of Business Venturing, 15, 411-432.

Lechner, C., \& Dowling, M. (2003). Firm networks: external relationships as sources for the growth and competitiveness of entrepreneurial firms. Entrepreneurship \& Regional Development, 15(1), 1-26.

Lin, N. (1999). Building a network theory of social capital. Connections, 22(1), 28-51.

Ministry of Youth, Sports \& Culture of Ethiopia. (2005). National youth policy. Retrieved on March 14, 2014 from http:// www.mysc.gov.et/youth.html.

NLFS. (2005).National Labour Force Survey.Central Statistical Authority of Ethiopia.

Olomi, D., \& Urassa, G. (2008). The constraints to access the capital by SMEs of Tanzania. Dar es Salaam: REPOA.

Osano, H., \& Languitone, H. (2016). Factors influencing access to finance by SMEs in Mozambique: case of SMEs in Maputo central business district. Journal of Innovation \& Enterpreneurship, 5, 13.

Phan, H. P., Wong, P. K., \& Wang, C. K. (2002). Antecedents to Entrepreneurship among University Students in Singapore: Beliefs, Attitudes and Background. Journal of Enterprising Culture, 10(2), 151-174.

Stam, W. (2010). Industry event participation and network brokerage among entrepreneurial ventures. Journal of Management Studies, 47(4), 625-653.

Storey, D. J. (1994). Understanding the small business sector. London; New York: Routledge. 
Talent Youth Association (TaYa). (2013). Young People and the Demographic Dividend.

Talent Youth Association (TaYa). (2014). Report.Ethiopia.

Tkachev, A., \& Kolvereid, L. (1999). Self-employment intentions among Russian students. Entrepreneurship and Regional Development, 11(3), 269-280.

Verheul, L., Thruik, R., \& Grilo, I. (2005). Determinants of self-employment preference and realization of women and men in Europe and the United States, 2005, EM Scales paper N200513. Zoetermeer: EIM Business and Policy Research.

Woods, A., \& Joyce, P. (2003). Owner-managers and the practice of strategic management". International Small Business Journal, 21(2), 181-195.

Zhao, H., Seibert, S. E., \& Hills, G. E. (2005). The mediating role of self-efficacy in the development of entrepreneurial intentions. Journal of Applied Psychology, 90(6), 1265.

Submit your manuscript to a SpringerOpen ${ }^{\circ}$ journal and benefit from:

- Convenient online submission

- Rigorous peer review

- Immediate publication on acceptance

Open access: articles freely available online

- High visibility within the field

- Retaining the copyright to your article

Submit your next manuscript at $>$ springeropen.com 